www.jmscr.igmpublication.org

Index Copernicus Value: 79.54

ISSN (e)-2347-176x ISSN (p) 2455-0450

crossref DOI: https://dx.doi.org/10.18535/jmscr/v7i5.74

\title{
A Clinico Epidemiological Study and Outcome of Burn Injury Patients Visiting Tertiary Care Centre at Gorakhpur District
}

\author{
Authors \\ Arushi Sumpriya ${ }^{1}$, Neha Priyanka ${ }^{2 *}$, Kavita Baranwal ${ }^{3}$, D.K. Srivastava ${ }^{4}$ \\ ${ }^{1,2}$ Assistant Professor, Deptt. of Community Medicine, B R D Medical College, Gorakhpur, UP, India \\ ${ }^{3}$ Associate Professor, Deptt. of Community Medicine, B R D Medical College, Gorakhpur, UP, India \\ ${ }^{4}$ Professor, Deptt. of Community Medicine, B R D Medical College, Gorakhpur, UP, India \\ *Corresponding Author \\ Neha Priyanka \\ Assistant Professor, Deptt. of Community Medicine, B R D Medical College, Gorakhpur, UP, India
}

\begin{abstract}
Objectives: To study the clinic epidemiological correlates of burn injury patients.

Study design: A cross- sectional study

Study Settings: Burn \& Plastic Surgery ward, Deptt of Surgery, B R D Medical College, Gorakhpur

Study Period: October 2016 to February 2017

Result: Out of 210 admitted burn patients, $41.4 \%$ were male and $58.6 \%$ were female subjects showing female predominance. Most of the burn patients belonged to 21-40 years of age group, rural areas, Hindu, unemployed and married. Majority were living in nuclear families (62.4\%) belonging to lower socioeconomic class. Maximum burns occurred in between 11 am- 5 pm (34.8\%). Thermal or flame burn was common and accidental in nature (88.6\%) with female predominance. Cases of domestic burns (86.2\%) were more as compared to the outdoor burn (13.8\%). The proportion of deep burns was found significantly higher in females (97.4\%).Majority of patients (59\%) were wearing synthetic clothes at the time of burn. Overall mortality was $46.2 \%$, although mortality was more in female subjects.

Keywords: Burn injuries, sociodemographic factors, hospital, outcome.
\end{abstract}

\section{Introduction}

Burn injury is one of the most severe trauma a person can experience and a life threatening state in which all of the main integrating systems in the body are affected ${ }^{1}$. Burn injury is the globally occurring health problem leading to high disability, disfigurement \& dependency. Burns are the fourth most common type of trauma worldwide $^{2}$. The majority of burn cases occur in low and middle-income countries and almost half occur in the WHO South-East Asia Region.
Burns are also a leading cause of disability and disfigurement. Estimated annual burn incidence in India is approximately 6 to 7 million $^{3}$. Apart from having painful physical trauma and complications like shock, sepsis contracture/ scar coping up during its acute phase, it is also associated with long term psychosocial consequences due to disfigurement and disability.

Keeping this in background, this study was undertaken with objectives to study the sociodemographic factors of burn patients in 
tertiary care centre, to find out the cause and outcome of burn patients admitted in Medical College, Gorakhpur, and to draw conclusion about preventive aspects of burn injuries.

\section{Materials and Methods}

An interview based cross-sectional study was conducted on all the patients who were admitted in Burn and Plastic Surgery ward of B.R.D. Medical College, Gorakhpur from October 2016 to February 2017. A total of 278 patients were admitted. Out of these, 68 either refused to give consent or took LAMA or expired within few hours of admission. Therefore a total of 210 patients were enrolled for socio-demographic profile and etiology of burn. An interviewer based detailed socio-demographic profile and etiology of burn questions were asked from the conscious patients who gave consent to participate in the study. In case of unconscious patients or patients less than 18 years of age or those who were unable to give the interview, these questions were asked from the attendants of the patient after taking their consent. Data regarding sociodemographic profile and etiology of burn patients were recorded on predesigned and pretested questionnaire. The data collected through questionnaire was entered in the MS Excel spread sheet and analysed using SPSS and chi-square test were applied to show significance between the variables.

\section{Results}

Table-1: Description of studied subjects according to their Sociodemographic profile $(\mathrm{N}=210)$

\begin{tabular}{|c|c|c|c|c|c|}
\hline \multicolumn{2}{|l|}{ Characteristics } & $\begin{array}{l}\mathbf{N}(\%) \\
(210)\end{array}$ & $\begin{array}{c}\text { Male } \\
(87 ; 41.4 \%)\end{array}$ & $\begin{array}{c}\text { Female } \\
(123 ; 58.6 \%)\end{array}$ & $\begin{array}{l}\text { Test of } \\
\text { significance }\end{array}$ \\
\hline \multirow[t]{4}{*}{ Age in years } & $<20$ & $64(30.5)$ & $29(45.3)$ & $35(54.7)$ & $\begin{array}{l}x^{2}=0.36 \\
p>0.05\end{array}$ \\
\hline & $21-40$ & $114(54.3)$ & $39(34.2)$ & $75(65.8)$ & $\begin{array}{l}x^{2}=4.72 \\
p<0.05\end{array}$ \\
\hline & $41-60$ & $25(11.9)$ & $15(60)$ & $10(40)$ & $\begin{array}{l}x^{2}=4.72 \\
p>0.05\end{array}$ \\
\hline & $>60$ & $7(3.3)$ & $4(57.1)$ & $3(42.9)$ & $\begin{array}{l}x^{2}=0.219 \\
p>0.05\end{array}$ \\
\hline \multirow[t]{2}{*}{ Area of residence } & Rural & $127(60.5)$ & 54 & 73 & \multirow{2}{*}{$\begin{array}{l}x^{2}=0.157 \\
p>0.05\end{array}$} \\
\hline & Urban & $83(39.5)$ & 33 & 50 & \\
\hline \multirow[t]{3}{*}{ Marital status } & Married & $125(54.5)$ & $47(35.2)$ & $78(64.8)$ & $\begin{array}{l}x^{2}=4.32 \\
p<0.05\end{array}$ \\
\hline & Unmarried & $76(36.2)$ & $34(44.7)$ & $42(55.3)$ & $\begin{array}{l}x^{2}=2.14 \\
p>0.05\end{array}$ \\
\hline & Widow/ widower & $9(9.3)$ & $6(66.7)$ & $3(33.3)$ & $\begin{array}{l}x^{2}=1.5 \\
p>0.05\end{array}$ \\
\hline \multirow[t]{2}{*}{ Religion } & Hindu & $196(93.3)$ & 83 & 113 & \multirow{2}{*}{$\begin{array}{l}x^{2}=1.021 \\
p>0.05\end{array}$} \\
\hline & Muslim & $14(6.7)$ & 4 & 10 & \\
\hline \multirow{6}{*}{$\begin{array}{l}\text { Educational } \\
\text { qualification }\end{array}$} & Illiterate & $66(31.4)$ & 21 & 45 & \\
\hline & Primary school & $36(17.1)$ & 16 & 20 & \\
\hline & Middle school & $33(15.7)$ & 13 & 20 & \\
\hline & High school & $28(13.3)$ & 13 & 15 & \\
\hline & Intermediate & $35(16.7)$ & 14 & 21 & \\
\hline & Graduate or above & $12(5.8)$ & 10 & 2 & \\
\hline \multirow[t]{2}{*}{ Occupation } & Employed & $66(31.4)$ & $57(86.4)$ & $9(7.3)$ & \multirow{2}{*}{$\begin{array}{l}x^{2}=80.091 \\
p<0.05\end{array}$} \\
\hline & Unemployed & $144(68.6)$ & $30(13.6)$ & $114(92.7)$ & \\
\hline \multirow[t]{2}{*}{ Type of family } & Nuclear & $131(62.4)$ & 47 & 84 & \multirow{2}{*}{$\begin{array}{l}x^{2}=4.421 \\
p<0.05\end{array}$} \\
\hline & Joint & $79(37.6)$ & 40 & 39 & \\
\hline \multirow{5}{*}{$\begin{array}{l}\text { Socioeconomic } \\
\text { status }\end{array}$} & Class I & $3(1.4)$ & 2 & 1 & \\
\hline & Class II & $9(4.3)$ & 2 & 7 & \\
\hline & Class III & $34(16.2)$ & & & \\
\hline & Class IV & 79 (37.6) & 37 & 42 & \\
\hline & Class V & $85(40.5)$ & 26 & 59 & \\
\hline
\end{tabular}


Table 1 shows, out of 210 burn patients $58.6 \%$ were female while $41.4 \%$ were male subjects. The male: female ratio was 1: 1.41 in our study showing female predominance. Most of the burn patients belonged to the age group of 21-40 years with female predominance i.e. 65.8\%. Overall predominance of burn cases were seen among rural inhabitants $(60.5 \%)$, married females (54.5\%), Hindus (93.3\%), illiterate groups $(31.4 \%)$ and in among those belonging to lower socioeconomic class (40.5\%). There was no significant association found among these groups. A majority of the burn patients were unemployed $(144 ; 68.6)$ while $66(31.4 \%)$ were employed. The proportion of unemployed female burn patients was found significantly higher as compared to unemployed male burn patients. In relation to type of family it was found that the majority of burn patients $131(62.4 \%)$ were living in nuclear families while 79 (37.6\%) were living in joint families. There was a significant association seen.

Table-2: Description of studied subjects according to the epidemiology of burn $(\mathrm{N}=210)$

\begin{tabular}{|c|c|c|c|c|c|}
\hline \multicolumn{2}{|l|}{ Characteristics } & $\begin{array}{l}\mathbf{N}(\%) \\
(210)\end{array}$ & $\begin{array}{c}\text { Male } \\
(87 ; 41.4 \%)\end{array}$ & $\begin{array}{c}\text { Female } \\
(123 ; 58.6 \%)\end{array}$ & $\begin{array}{l}\text { Test of } \\
\text { significance }\end{array}$ \\
\hline \multirow[t]{4}{*}{$\begin{array}{l}\text { Time of } \\
\text { incidence of burn }\end{array}$} & 5am-11am & $63(30)$ & $15(23.8)$ & $48(76.2)$ & $\begin{array}{l}x^{2}=7.5 \\
p<0.05\end{array}$ \\
\hline & $11 \mathrm{am}-5 \mathrm{pm}$ & $73(34.8)$ & $39(53.4)$ & $34(46.6)$ & $\begin{array}{l}x^{2}=5.9 \\
p<0.05\end{array}$ \\
\hline & $5 \mathrm{pm}-11 \mathrm{pm}$ & $66(31.4)$ & $29(43.9)$ & $37(56.1)$ & $\begin{array}{l}x^{2}=0.12 \\
p>0.05\end{array}$ \\
\hline & $11 \mathrm{pm}-5 \mathrm{am}$ & $8(3.8)$ & $4(50)$ & $4(50)$ & $\begin{array}{l}x^{2}=0.02 \\
p>0.05\end{array}$ \\
\hline \multirow[t]{3}{*}{ Nature of burn } & Accidental & $186(88.6)$ & 77 (41.4) & $109(58.6)$ & $\begin{array}{l}x^{2}=0.01 \\
p>0.05\end{array}$ \\
\hline & Homicidal & $18(8.6)$ & $8(44.4)$ & $10(55.6)$ & $\begin{array}{l}x^{2}=1.04 \\
p>0.05\end{array}$ \\
\hline & Suicidal & $6(2.8)$ & $2(33.3)$ & $4(66.7)$ & $\begin{array}{l}x^{2}=0.17 \\
p>0.05\end{array}$ \\
\hline \multirow[t]{2}{*}{ Place of burn } & Domestic & $181(86.2)$ & $61(33.7)$ & $120(66.3)$ & $x^{2}=32.25$ \\
\hline & Outdoor & $86(41)$ & $55(63.3)$ & $31(26.1)$ & $\mathrm{p}<0.05$ \\
\hline \multirow[t]{4}{*}{ Type of burn } & Thermal & $162(77.1)$ & $52(32.1)$ & $110(67.9)$ & $\begin{array}{l}\mathrm{x}^{2}=23.77 \\
\mathrm{p}<0.001\end{array}$ \\
\hline & Scald & $16(7.6)$ & $8(50)$ & $8(50)$ & $\begin{array}{l}x^{2}=0.21 \\
p>0.05\end{array}$ \\
\hline & Chemical & $3(1.4)$ & $2(66.7)$ & $1(33.3)$ & $\begin{array}{l}x^{2}=0.09 \\
p>0.05\end{array}$ \\
\hline & Electrical & $29(13.8)$ & $25(86.2)$ & $4(13.8)$ & $\begin{array}{l}x^{2}=25.7 \\
p<0.001\end{array}$ \\
\hline \multirow[t]{2}{*}{ Material worn } & Synthetic & $124(59)$ & $32(36.7)$ & $92(73.9)$ & $x^{2}=241.59$ \\
\hline & Cotton & $86(41)$ & $55(63.3)$ & $31(26.1)$ & $\mathrm{p}<0.001$ \\
\hline \multirow[t]{2}{*}{ Degree of burn } & Superficial & $78(37.1)$ & $46(52.8)$ & $32(26)$ & $x^{2}=15.743$ \\
\hline & Deep & $132(62.9)$ & $41(47.2)$ & $91(74)$ & $\mathrm{p}<0.001$ \\
\hline \multirow[t]{4}{*}{$\begin{array}{l}\text { Total body } \\
\text { surface area }\end{array}$} & $1-25 \%$ & $38(18.1)$ & $30(78.9)$ & $8(21.1)$ & $\begin{array}{l}x^{2}=0.06 \\
p>0.05\end{array}$ \\
\hline & $26-50 \%$ & $83(39.5)$ & $33(39.7)$ & $50(60.3)$ & $\begin{array}{l}x^{2}=0.06 \\
p>0.05\end{array}$ \\
\hline & $51-75 \%$ & $42(20)$ & $17(40.5)$ & $25(59.5)$ & $\begin{array}{l}x^{2}=0.002 \\
p>0.05\end{array}$ \\
\hline & $76-100 \%$ & $47(22.4)$ & 7 (14.9) & $40(85.1)$ & $\begin{array}{l}x^{2}=16.19 \\
p<0.001\end{array}$ \\
\hline
\end{tabular}

Table 2 depicts that maximum number of burn cases occurred in between 11 am- 5 pm (34.8\%) which was statistically significant $(\mathrm{p}<0.05)$. It was found that the time of occurrence of burn for majority of female patients was in between 5 am11 am $(76.2 \%)$ while for male patients maximum 
number of burns occurred in between 11 am- 5 pm (39\%).In majority of cases the nature of burn was accidental $(88.6 \%)$ with female predominance, followed by homicidal $(8.6 \%)$ and suicidal (2.8\%). Domestic burn (86.2\%) occurred significantly higher as compared to outdoor burn $(13.8 \%)(\mathrm{p}<0.05)$. Domestic burn showed female predominance. About $62.9 \%$ showed deep burn which was statistically significant $(\mathrm{p}<0.001)$. Most of the burn cases occurred in those who were wearing synthetic dress material and there was significant association reported with the material worn during the burn. Thermal or flame burn was common $(77.1 \%)$ which was statistically significant $(\mathrm{p}<0.001)$, followed by electric (13.8\%) and scald (1.2\%). About 39.5\% showed 26- $50 \%$ burn while $22.4 \%$ showed more than $75 \%$ total body surface area (TBSA) involvement which was statistically significant $(\mathrm{p}<0.001)$.

Table-3: Description of studied subjects according to the OUTCOME of burn $(\mathrm{N}=210)$

\begin{tabular}{|l|c|c|c|}
\hline Outcome & N (210) & Male (87) & Female (123) \\
\hline Recovery & $2(0.9)$ & $2(2.3)$ & 0 \\
\hline Residual functional disability & $18(8.6)$ & $13(14.9)$ & $5(4.1)$ \\
\hline $\begin{array}{l}\text { Cosmetic disfigurement along with residual } \\
\text { functional disability }\end{array}$ & $32(15.2)$ & $24(27.6)$ & $8(6.5)$ \\
\hline Cosmetic disfigurement & $93(44.3)$ & $44(50.6)$ & $49(39.8)$ \\
\hline Death & $97(46.2)$ & $28(32.2)$ & $56.1)$ \\
\hline
\end{tabular}

Table 3 depicts that among the burn patients admitted maximum number of burn patients 97 (46.2\%), expired, 93 (44.3\%) had cosmetic disfigurement 32 (15.2\%) had cosmetic disfigurement along with residual functional disability, $18(8.6 \%)$ had residual functional disability while only $2(0.9 \%)$ recovered completely.

Among the male burn patients admitted maximum number of patients $44(50.6 \%)$ had cosmetic disfigurement, 28 (32.2\%) died, 24 (27.6\%) had cosmetic disfigurement along with residual functional disability, $13(14.9 \%)$ had residual functional disability, and $2(2.3 \%)$ recovered completely.

Among the female burn patients admitted maximum number of patients $69(56.1 \%)$ expired, $49(39.8 \%)$ had cosmetic disfigurement, 8 (6.5\%) had cosmetic disfigurement along with residual functional disability and $5(4.1 \%)$ had residual functional disability.

\section{Discussion}

Burn injuries are among the most devastating of all injuries and a major global public health crisis ${ }^{4}$. Almost $95 \%$ of global burn deaths and disabilities are estimated to occur in low- and middle-income countries of the world ${ }^{5}$.

In our study, male:female ratio was 1:1.41 showing female predominance especially between 21 and 40 years of age similar with Verma et. $\mathrm{al}^{6,7}$. Our data showed that the age group between 21 and 40 years is the most vulnerable to burn injuries for both genders, which is consistent with findings from other studies ${ }^{6,7}$. Thus, overall female subjects were more likely to be at risk of burn injuries especially between 21 and 40 years of age owing to their domestic chores and invariably using unsafe equipments at home, and this is similar to other studies ${ }^{6,7}$.

In our study, majority of the patients were Hindus and belonged to rural background which was supported by other studies also owing to their population proportion. Regarding marital status, most of the burn patients were married, especially married females were more victims, supported by another study ${ }^{6,8}$. In our study majority of burn patients were illiterate $(31.4 \%)$. Majority of patients $(68.6 \%)$ were unemployed and among the nonworking class, housewives also similar to Gandhari et. $\mathrm{al}^{7,8}$. 
In our study, majority of burn patients belonged to nuclear families. Most of the cases $(40.5 \%)$ were from class $\mathrm{V}$ (Lower) socioeconomic group followed by $37.6 \%$ from class IV (Upper Lower) socioeconomic group ${ }^{6,7}$.

Maximum number of burns (37.78\%) occurred between 11 am to $5 \mathrm{pm}$ which is significant $(\mathrm{p}<0.05)$ while minimum number of burns $(3.8 \%)$ occurred between $11 \mathrm{pm}$ to $5 \mathrm{am}$ when most of the people are sleeping. It is clear that one is busy during morning and afternoon hours in cooking and a mistake with fire in hurry can result in burns. Only $3.8 \%$ of burns occurred at night between $11 \mathrm{pm}$ to $5 \mathrm{am}$ when most of the people are sleeping supported by another study ${ }^{8,9}$.

Most of the burn injuries were accidental in nature, consistently found with others studies and flame burns or thermal burns were the most common causative factor for sustaining burns and are similarly found in other reports ${ }^{6,8}$. Majority of burns $(86.2 \%)$ took place at home and $13.8 \%$ at work place ${ }^{7,8}$.

In our study conducted it was found that at the time fire caught them $73.9 \%$ had synthetic clothing and $26.1 \%$ had cotton clothing. It may be because Indian women wear loose flowing synthetic garments which can catch fire easily and cause extensive burn injury. It was found similar to study done by Shankar et. $\mathrm{al}^{9}$.

In our study, $62.4 \%$ had deep burn while $37.6 \%$ had superficial burn supported by other studies ${ }^{6}$. In the present study done it was found that TBSA was highest in $26-50 \%$ burn $(39.5 \%)$ followed by $76-100 \%$ in $22.3 \%$ patients, $51-75 \%$ in $20 \%$ patients and lastly $1-25 \%$ burn in $18.1 \%$ patients. The mean TBSA of male burn patients was $39.8 \%$ while that of female burn patients was $60.2 \%$. It was supported by other studies ${ }^{6,7}$.

Mortality rates were found about $46.2 \%$ similar in other studies. Our study reported that burn mortality was more in female than male subjects ${ }^{8}$.

\section{Conclusion and Recommendation}

In our study incident of burn was more among females than males. A majority of burn patients lie in the age group of $21-40$ years $(114 ; 54.3 \%)$. Most of the cases among these age group were domestic. Lack of proper knowledge is the keyhole of most of these accidents. There was a higher percentage of burn cases reported among rural, illiterate, married Hindu females those who were belonging to nuclear families and lower socioeconomic class. The public especially housewives and young girls should be properly educated about use of LPG gas cylinder and stoves. Awareness should be generated regarding wearing of well fitted cotton clothes while handling kitchen works.

Post burn patient should be counselled so that they (i) can maintain a normal routine. (ii)Take time to do things that feel good to them. (iii) Do not try to block out thoughts of what has happened. (iv)Practice relaxation exercises. (v) Try to return to normal work as early as possible.

Support from family and friends are strongly recommended. Counselling of spouse/family members is strongly recommended. The general public should be emphasized on prevention from burn rather than reacting violently to it.

\section{References}

1. Mahadevan SV, Garmel GM, editors. An introduction to clinical emergency medicine 2nd ed. Cambridge: Cambridge University Press; 2012: pp. 216-219

2. Fact Sheet Number 365 Burns [internet]. World Health Organization; 2012 May. Available

from:http://who.int/mediacentre/factsheets/ fs365/ en/index.html. [Cited on 2013 19th October].

3. Gupta JL, Makhija LK, Bajaj SP. National programme for prevention of burn Injuries. Indian J PlastSurg 2010;43:S6-10.

4. Forjuoh SN. Burns in low- and middleincome countries: a review of available literature on descriptive epidemiology, risk factors, treatment, and prevention. Burns 2006;32(5):529-37. 
5. Kumar S, Ali W, Verma AK, Pandey A, Rathore S. Epidemiology and mortality of burns in the Lucknow Region, India - a 5 year study. Burns 2013;39(8):1599-605.

6. Santosh Kumar Verma1, Shobha Chaturvedi2, Shubhanshu Gupta1; International Journal of Medical Science and Public Health | 2016 | Vol 5 | Issue 112290

7. Gandhari Basu1, Subikas Biswas2, Chitra Chatterjee3, Reshmi Mondal4, Prasanta Kumar Sarkar5, Kingsuk Sarkar1; National Journal of Community Medicine; Volume 5; Issue 3; April- June 2014.

8. Haralkar Santosh Jagannath1, Tapare Vinay S2, RayateMadhavi V3; NATIONAL JOURNAL OF COMMUNITY MEDICINE 2011 Volume 2 Issue 1

9. *Shankar Gowri, **Naik Vijaya A, **Rajesh Powar, *Ravindra Honnungar, *** Mallapur M D; J Indian Acad Forensic Med. October-December 2012, Vol. 34, No. 4. 